\title{
VIDEO ANIMATION AS TEACHING MEDIA IN ELT
}

\author{
Titis Sulistyowati \\ Universitas Muria Kudus
}

\author{
Testiana Deni Wijayatiningsih \\ Universitas Muhammadiyah Semarang
}

\begin{abstract}
The issue of TPACK (Technology Pedagogical Content Knowledge) offers a problem solution for teachers who are interested in implementing blended learning. Education and Technology have become an important aspect in every student's daily life beyond the school and within the classroom. Experts now create software that facilitates teachers in creating animated videos which contain pedagogical knowledge. One of them is Videoscribe which can be used to present learning content by combining interesting images, sounds, and graphs to attract students to enjoy the learning process. The features provided by this software are varied; they enable teachers to design learning media that can be adjusted to meet the goal of the lesson. This paper will elaborate on how teachers can design an interesting and engaging learning media to meet the students' needs and to achieve learning objectives by using the software.
\end{abstract}

Key words: Videosribe, Teaching Media, ELT, Technology, and Pedagogy

\section{INTRODUCTION}

Technology is now an integral part of education. It offers much potential to enhance teaching and learning not only in the classroom but beyond it. Teachers play an indispensable role in leveraging the powerful potential of technology in classroom language learning particularly as they determine the learning needs of the students and how these needs can be approached through instructional activities. Integrating technology in the English language classroom requires that teachers not only know about the technology. This knowledge needs to relate to knowledge in the areas of pedagogy and content too which are important aspects of effective pedagogy (Ramanair, 2017).

Technology can be used to help teachers in creating interesting media to introduce the students to the topics they bring in the classroom. Educational content technology could also help the teachers in preparing the students becoming independent learners. Technology facilitates the students to learn beyond the classroom and they can create their own learning environment. Technology can stimulate students' interest and motivate students to learn. Reading books, doing school paper-based tasks, sitting and listening to the teachers in the classroom can be boring activities for the students.

To avoid the monotonous teaching and learning process, some education practitioners suggest that teachers should implement Technology Pedagogical Content Knowledge (TPACK). On the other hand, many teachers still face difficulties in implementing the concept of TPACK while they are teaching. Instead of high cost, limited access, and time allotment for preparation, the lack of technological knowledge seems to be the biggest barriers to classroom implementation. 
TPACK represents the issues of the knowledge that should be possessed by professional teachers. Besides pedagogical knowledge and content knowledge, teachers now should also be able to use technology to support their teaching practice. Technological Knowledge concerns teachers' understanding of education and technology. It considers the possibilities of technology application for a specific subject area. A teacher should be able to recognize the moment when he should support learning with technology, and continually learning and adapting to new technology offerings. Teachers should understand how the subject matter can be delivered to students through different media, and considering which specific technology which might be best suited for specific learning purposes.

Now teachers are expected to be able to develop learning media which adopt current technology, teachers should not only prepare paper-based media in the form of pictures, charts, or graph but they need to vary and equipped with digital media. Alwi says (2016) that teachers must be creative in preparing teaching materials. They should be able to create teaching media and not just adopting.

It's important to have clear, goals or outcomes for a teacher in designing teaching media. Teaching media is also the source of learning for students. Students are now equipped with technology and it has been part of their daily life as well as their education. Students and teachers are having different backgrounds of education; however, teachers now should be technology literate and able to use technology to facilitate their students to make engaging teaching and learning process. Therefore teachers should be familiar with some modern application which can help them to create media of teaching. Teachers should get involved in training that can help them in learning useful and creative media to support their teaching process.

Wikramanayake (2005) says that teachers could present explicit knowledge by using different teaching media. Text, graphics, animation, sound, and video can be used to create an engaging learning atmosphere. Animation offers an interesting presentation. The visual effect on animated pictures will improve the quality of the learning process. Some visual effects; like a moving object presented on the screen, user-controlled movement of an object, bitmap flipping, and full animation files will create students' excitement. To create animated media of teaching, teachers can use multifunctional software, videoscribe-Sparkol. This software is usually used to create animated media of teaching. This paper will elaborate on the use of Videosribe for designing media of teaching as the implementation of Technology Pedagogical Content Knowledge (TPACK).

\section{TPACK}

Walsh (2010) claims that the increased accessibility and mobility of digital technology have rapidly changed the way people communicate and these changes intensify the need to clarify the relationship between literacy and technology. Currently, people tend to interact instantly by using mobile phone technology and with different types of devices utilized by internet connection. Social interaction has changed rapidly accompanied by technological developments and the new 'textual landscape' (Carrington, 2005 in Walsh, 2010). 
People now are easily connected via various social networking sites (e.g. Whatsapp, Facebook, YouTube, and Tweeter). Information is now instantly be received by internet users. We can participate in a virtual life through virtual gaming, online courses, and webinar. These digital communications influence the way people expose themselves and the way individuals' connection is developed.

Walsh (2010) argues that changes to literacy pedagogy are gradually occurring in classrooms in response to contemporary communication and learning contexts. Teachers should adjust themselves to this curriculum by preparing and revising the existing curriculum. Teachers and educational researchers may respond to the changes in digital technologies by adjusting the educational curriculum and policies. Technological literacy needs to be included within the current curriculum in national education contexts. New language education and literacy focus are designed within the framework of multimodal literacy, the literacy that is relevant to the current paradigm for reading, viewing, responding to and producing multimodal and digital texts.

The concept of TPACK is created to educate teachers about the new framework to teach the learning materials which includes three essential aspects. They are technology, pedagogy, and content knowledge. To integrate the three aspects, teachers and policymakers need to have the same understanding to include them in collaborative curriculum design (Boschman, McKenney, \& Voogt, 2014). To adopt technology for education, policymakers should also consider the teachers' readiness for technology literacy.

Some researchers reviews that TPACK should have been done related to teacher professional development. Forssell (2011) reported in his dissertation that TPACK often related to student use of computers in the classroom. It is very important to share common ground on TPACK understanding between teachers. He found teachers with higher TPACK confidence were likely to have explored a greater breadth of activities related to 21 st-century skills with their students. Teachers should acquire the capability to adjust technology to the subject matter to achieve learning outcomes.

The conception of TPACK has developed from time to time and through a series of researches and publications. In this paper, the writer refers to the descriptions of the framework found in Koehler and Mishra (2009) explain TPACK model (see Figure 1). There are three main components of teachers' knowledge: content, pedagogy, and technology. Equally important to the model are the interactions between and among these bodies of knowledge, represented as PCK, TCK (technological content knowledge), TPK (technological pedagogical knowledge), and TPACK. 


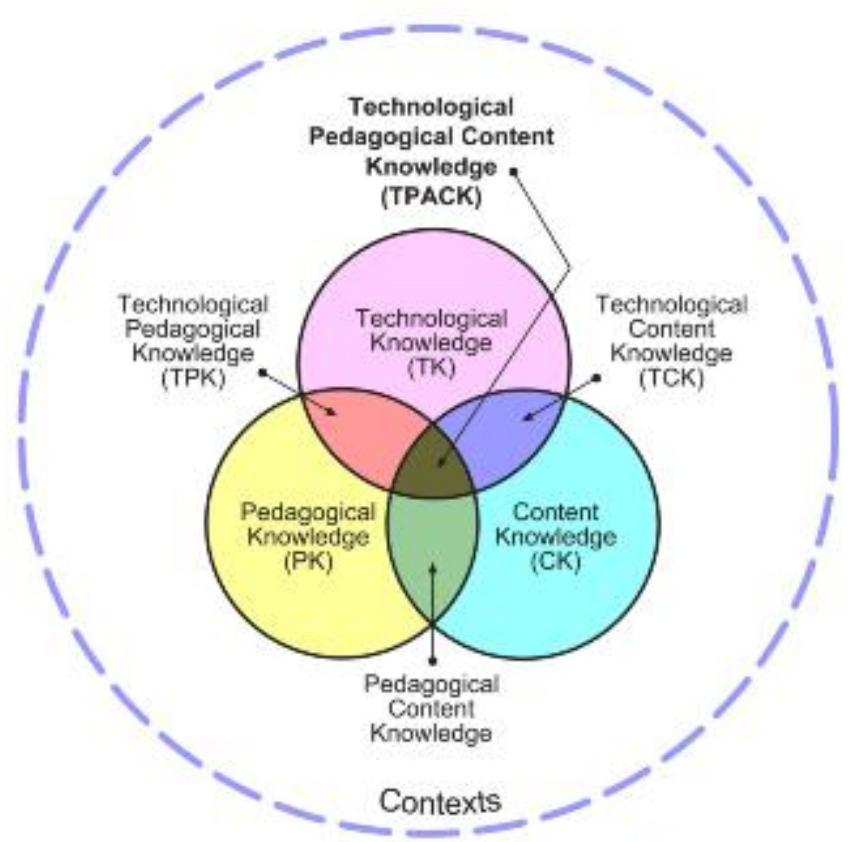

Figure 1. The TPACK framework and its knowledge

Content knowledge (CK) is teachers' knowledge about the subject matter to be learned or taught. Shulman (1986) notes that this knowledge would include knowledge of concepts, theories, ideas, organizational frameworks, knowledge of evidence and proof, as well as established practices and approaches toward developing such knowledge. Pedagogical knowledge (PK) refers to teachers' understanding of the processes and practices or methods of teaching and learning. These aspects include all the learning purposes, aims, and outcomes. This generic form of knowledge applies to understand how students learn, general classroom management skills, lesson planning, and student assessment. PCK is the notion of the transformation of the subject matter for teaching. Specifically, according to Shulman (1986), this transformation occurs as the teacher interprets the subject matter, finds multiple ways to represent it and adapts and tailors the instructional materials to alternative conceptions and students' prior knowledge. PCK covers the core business of teaching, learning, curriculum, assessment and reporting, such as the conditions that promote learning and the links among curriculum, assessment, and pedagogy. The definition of TK used in the TPACK framework is close to that of the fluency of Information Technology. TPK is an understanding of how teaching and learning can change when particular technologies are used in particular ways.

Technological pedagogical content knowledge (TPACK) is an understanding that emerges from interactions among content, pedagogy, and technology knowledge. TPACK is different from the knowledge of all three concepts individually. TPACK is the basis of effective teaching with technology, requiring an understanding of the representation of concepts using technologies; pedagogical techniques that use technologies in constructive ways to teach 
content; knowledge of what makes concepts difficult or easy to learn and how technology can help redress some of the problems that students face; knowledge of students' prior knowledge and theories of epistemology; and knowledge of how technologies can be used to build on existing knowledge to develop new epistemologies or strengthen old ones (Khoehler \& Mishra, 2009).

\section{Animated Video for Teaching}

Much research has been done to examine the effectiveness of using animated video for teaching English. Khalidiyah (2015) reports that the finding of her research indicates that the animated video is significantly effective in improving students' reading comprehension. The questionnaire result shows most of the students give positive responses toward the use of animated video. They say that the animated video improves their reading comprehension, motivate them, stimulate their interest and increase their curiosity on the subject.

Beer (2012) reports that he can improve students' writing self-regulation through the use of a video scribed animation in an online environment. He concludes that he has achieved teaching success because teaching college students self-regulation skills have proven difficult in the past. He adds the success might because students find the video scribed animation to be entertaining, engaging, and educating.

Ramadhika (2014) explains that his research on the use of animation videos in EFL classroom show positive result. It is effective to improve the students' listening skills and the teacher's performance. Some good improvements are realized in some aspects such as students' pronunciation and vocabulary. Students are actively following all the activities by showing good motivation in classroom discussion and interaction among students. They do not hesitate to do peer correction and showing high interest because they find the animation interesting. As the result, they carefully watch the video and listen to the audio very well.

\section{Videoscribe-Sparkol Application}

Videoscribe-Sparkol is software for creating whiteboard animations automatically. It was launched in 2012 by UK company Sparkol. VideoscribeSparkol can present learning content by combining interesting images, sounds, and designs so students can enjoy the learning process. Videoscribe-Sparkol is multifunctional software; it can be used for various teaching activities. This application can be used to create highly animated designs easily. A year after it was released and published, it already has more than 100,000 users. (Zahra, 2017; Wulandari, 2016)

The features provided by this software enable creators to design interesting learning media that can be adapted and suited to the desired learning subjects. Besides by using the features provided in the application, users can create animated designs, graphics, and images following their needs and then imported into the software. To make it more interesting users can also dub and add sound or music depending on their need and they can adjust the media base on the learning goal. 
Videoscribe making can also be done offline so it does not depend on internet services, this will certainly make it easier for teachers to make learning media using videoscribe sparkol. Users only need to download software and install it on their PC.

Here are some advantages of using videoscribe:

1. Videoscribe can be used for online business purposes. Marketing ideas can be applied via videoscribe.

2. Videoscribe can be used for educators/teachers or lecturers as an introduction to learning.

3. Videoscribe is used as a presentation media.

4. Demonstrate the ability to think and combine it through animated videos.

Here are the steps for using Videoscribe in the project of making animationbased learning videos. We will learn how to make learning videos or commonly referred to as Whiteboard Animation. This animated drawing uses the Sparkol Videoscribe application which is an application to create animated presentation media with white background as unique and interesting presentation media (Fahdisjro, https://www.academia.edu/36071927/)

\section{First step: Making Storyline}

Storyline is a text designed as the basis of the idea to be presented in the animated video. The core flow of this story is organized as sequences of parts in the overall topic of the idea, basically the learning topic. The goal is that we have clear guidelines in designing the sequence of the story. It represents what we will do to make the animation conceptualized. So this storyline is very important because we need a guideline or concept before making the learning media. Therefore a guide like this will make it easier for us in the process of making the learning video.

\section{Second Step: Prepare Assets}

The assets here are the content that will be presented in a show on the VideoScribe application. At least two types of assets need to be prepared, namely visual assets (images) and audio assets (sound music). Image visual assets here we can use the base library feature available on the application Videoscribe. Or we can use images that we have made ourselves. It is recommended to use SVG (Scalable Vector Graphic) format. SVG is a format best when displaying Vector graphics compared to using PNG, JPG or GIF format. The application can be used to create SVG image assets such as Adobe Illustrator, Coreldraw or Inkscape.

The audio (music) assets are music illustrations that are used when accompanying each slide inside learning animation videos. For this musical illustration, it is recommended to use music that is legal (free royalty). The goal is when the video that we have created is uploaded to Youtube, it is not blocked because of it violating copyright. Several websites provide free royalty music like www.youtube/audiolibrary/music and www.bensound.com

\section{Step Three: Install the VideoScribe Application}


Before we make an animation-based learning video, of course, our computer must first already on the Videoscribe application. This application, we can get through the website page with the address www.videoscribe.co. Please download the application first and install it on your computer. After the Videoscribe application is installed, then we open the application.

Fourth Step: Entering Visual Assets

After the Videoscribe application is installed, then we open the application. In this initial view, we are presented an introduction, introduction to how to make videos using the application Videoscribe.

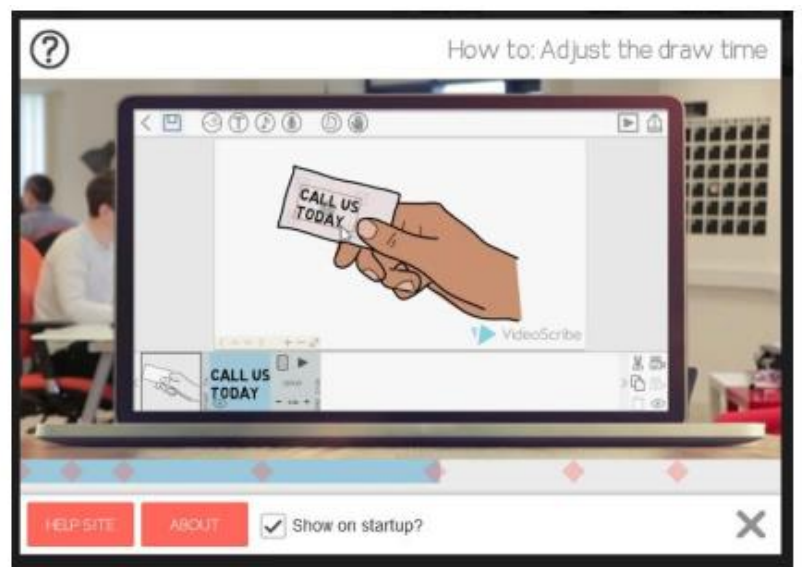

After we understand the features available on the Videoscribe application, the next step is to stay insert assets or content on the canvas in accordance with the prepared storyline. For the customization of assets that we have put on the canvas, click the "Properties" icon on the panel object-line.

\section{Step Five: Enter Voice Assets}

In the next step, we will include the voice of the verbal narrative. The goal is to make our animated videos more interactive. So the animation that we make is not only a visual animation but also verbally explain. Click the "Voice Over" icon on the toolbar panel at the top. Then we have presented the choice, whether the sound that we will enter from the recording directly or from the recording sound that we have previously made or sourced from the internet.

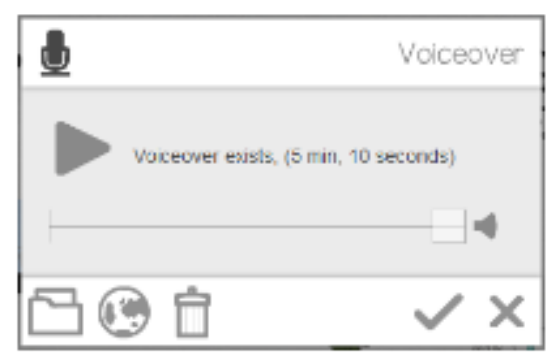

Sixth Step: Entering Music Assets 
Furthermore, for the animated video of the learning that we make to be more alive, we enter the illustration music into animation. We click the "Music Track" icon. Then we are presented with a choice of several musical choices available in the base library. We can use one of them, or we can also use the music that we have we prepare beforehand. We click on the "Folder" icon, then we find the location where the music is stored we prepare. Then specify the selected music file, click "Open" and OK.

\section{Seventh Step: Animated Video Publication (Render)}

The final step in making this animation-based learning video is publication. This publication is the process of compiling assets or content that we have created on the Videoscribe application to be a whole video animation. Click the "publish" icon. Then we will present several options. We can publish videos offline or online. If we publish offline, we select the "Create" option video file ", then we are presented with choices such as the type of video, size, and frame rate. Type the name of the video and $\mathrm{OK}$.

\section{CONCLUSION AND SUGGESTION}

The conception of TPACK has offered many benefits to ELT. As part of language teacher development, technology literacy for teachers should have become a necessity for the sake of students'learning improvement. Amination or moving pictures for teaching media is one of the realizations of TPACK conception. Animated videos can be used for teaching language skills such as writing, listening, reading and speaking. The animated teaching media present audiovisual and moving pictures. The videos represent the technology are used for teaching materials. They should have been modified and adjusted to the learning needs and purposes.

Training for teachers is important to introduce the teachers to useful software apps. The training should be provided by the experienced teacher and multimedia training center through individual instruction and small groups of teachers with personal computer software utilization. Teachers need to be literate of any modern way of developing teaching and learning media. They need to learn software application which facilitates them in creating interesting and engaging animated media for teaching. Technology training is intended to help the teacher to choose the learning topics that will be designed and to assist the teachers to create animated videos using modern apps.

\section{REFERENCES}

Alwi, Zahra, Abdullah Idi, dan Nurhayati. (2016). Perception and need analysis of development poem teaching materials based on local wisdom. This paper waspresented at $2^{\text {nd }}$ SULE-IC 2016, Sriwijaya University, Palembang, October 7-8 2016.

Beer, Jonathan S. (2012) Using Online Video Scribed Animation to Teach Writing Self-regulation. Thesis. University of Guelph, Ontario, 
Canada,https://pdfs.semanticscholar.org/c40e/8524d1736c3401d878787a 3aaecd699e2330.pdf accessed at 2nd July 2019

Boschman, F. B., McKenney, S., \& Voogt, J. (2015). Exploring teachers' use of TPACK in design talk: The collaborative design of technology-rich early literacy activities. Computers \& education, 82, 250262. https://doi.org/10.1016/j.compedu.2014.11.010 accessed at 2nd July 2019

Fahdisjro. ). Tutorial Video Scribe Membuat Video Animasi Pembelajaran. https://www.academia.edu/36071927/Tutorial_ Video_Scribe_Membuat_Video_Animasi_Pembelajaran?auto=download accessed at 5 July 2019

Forssell, Karin Sigrid. (2011). Technological Pedagogical Content Knowledge: Relationships To Learning Ecologies And Social Learning Networks. Dessertation. Graduate Studies Of Stanford University.https://web.stanford.edu/ forssell/dissertation/forssell_dissert ation_2011.pdf accessed at 30 June 2019

Khalidiyah, Hanifah. (2015). The Use of Animated Video in Improving Students' Reading Skill (A Quasi-Experimental Study of Seventh Grade Student at A Junior High School in Jalancagak, Subang). Journal of English and Education, 3(1)- 2015, 59-79

Koehler, M. J., \& Mishra, P. (2009). What is technological pedagogical content knowledge? Contemporary Issues in Technology and Teacher Education, $9(1)$,

60-70 https://www.researchgate.net/publication/241616400_What_Is_Technolo gical_Pedagogical_Content_Knowledge accessed at 4th July 2019

Ramadhika, Boris. (2014) Improving Students' Listening Skills Using Animation Videos For The Eighth Grade Students Of SMP N 6 Magelang In The Academic Year Of 2013/2014. Thesis. Yogyakarta State University

Ramanair, Joseph., Rethinsamy, Souba \& Misieng, Jecky. (2017). The Technological, Pedagogical and Content Knowledge (TPACK) of Tertiary Level English Language Instructors in Integrating Technology in Language Classrooms. E-Proceeding of The 6th Global Summit On Education 2017 (Gse 2017). (E-ISBN 978-967-0792-224).Https://Www.Researchgate.Net/Publication/321758402 accessed at 2nd July 2019

Shulman, Lee S. (1986)Those Who Understand: Knowledge Growth in Teaching . Educational Researcher, Vol. 15, No. 2 (Feb., 1986), pp. 4-14 URL: http://www.jstor.org/stable/1175860 . accessed at 3rd July 2019 
PROMINENT Journal, Volume 2, Number 2, July 2019

Walsh, Maureen (2010) Multimodal Literacy: What does it means for Classroom Practice? Australian Journal Of Language And Literacy, Vol. 33, No. 3, 2010, Pp. 211-239 https://www.researchgate.net/publication/267398684_Multimodal_literac y_What_does_it_mean_for_classroom_practice accessed at 2nd July 2019

Wikramanayake, G.N. (2005). Impact of Digital Technology on Education. Thesis. University of Colombo https://www.researchgate.net/publication/216361364_Impact_of_Digital _Technology_on_Education accessed at 1st July 2019

Wulandari, Diah Ayu. (2016). Pengembangan Media Pembelajaran Menggunakan Sparkol Videoscribe Dalam Meningkatkan Minat Belajar Siswa Pada Mata Pelajaran Ipa Materi Cahaya Kelas Viii Di Smp Negeri 01 Kerjo Tahun Ajaran 2015/ 2016. Skripsi. Universitas Negeri Semarang

Zahra A., Asnimar, Srirarasati, dan Yenny L. (2017) Pemanfaatan Media Videoscribe-Sparkol Untuk Meningkatkan Budaya Literasi Guru Dan Peserta Didik. Makalah Seminar Nasional, Sabtu 25 November 2017, PPS Unsri : https://www.researchgate.net/publication/323242813 accessesed at 2nd July 2019 